\title{
THE USE OF COMMUNICATIVE STRATEGIES IN NARRATIVE DISCOURSE: A CASE STUDY OF A LEARNER OF MOROCCAN ARABIC AS A SECOND LANGUAGE
}

\author{
Ahmed Fakhri \\ University of Michigan
}

\begin{abstract}
Research in second language learners' communicative strategies has provided an elaborate framework for analyzing how learners manage to convey meanings and messages in spite of their limited "knowledge" of the target language. Many studies (e.g., Færch and Kasper 1983) have dealt with the identification and classification of communicative strategies (CSs). This paper investigates a new aspect of the use of CSs: the interaction between the application of CSs and narrative discourse features.

Twelve narratives were collected from a learner of Moroccan Arabic as a second language over a four-week period during daily conversation sessions in the target language. The analysis of the data draws upon research in narrative discourse (e.g., Labov 1972) and language learners' CSs (e.g., Tarone 1980; Færch and Kasper 1983). The study suggests that the subject resorted to a number of strategies to compensate for her linguistic deficiencies and that the application of these strategies was not random but constrained by narrative discourse features. The limitations of this study are discussed and suggestions for further research made.
\end{abstract}

In research on the nature of interlanguage (Selinker 1972), reference has been made to strategies used by second language learners in their attempt to communicate despite their limited "knowledge" of the target language (TL) (Varadi 1973; Tarone 1977, 1979; Galvan and Campbell 1979; Færch and Kasper 1983).' The theoretical and empirical studies of these communicative strategies (CSs) have provided an elaborate framework for analyzing how learners manage to convey "difficult" meanings and messages. They have dealt with the identification and classification of CSs as well as with various problems encountered by researchers in their investigation of these strategies (cf. Færch and Kasper 1983). However, an area of investigation which is left untouched concerns the interaction between the application of CSs and certain discourse features. Corder (1983) stresses the importance of investigating the factors that determine which types of CSs are adopted by the learner and how these CSs are

\footnotetext{
'I would like to thank Dan Douglas, Deborah Keller-Cohen, and Larry Selinker for helpful comments on an earlier version of this paper. Any errors are my own.
} 
manipulated. I would suggest here that the way CSs are used is in part determined by the discourse genre in which they appear.

The present study seeks to provide some insights into the use of CSs within a particular discourse genre, namely, narrative discourse. Specifically, I will try to show that in the narrative discourse of a learner of Moroccan Arabic (MA) as a second language, the application of CSs is not random but rather is constrained by discourse features.

The first section of the paper deals with the typology of the CSs used by the subject and the criteria employed for their identification. In the second section, I will discuss how the application of these strategies is constrained by narrative discourse features. First, however, a word about the subject and the data under study is in order.

The subject is a female adult speaker of English who spent three years in Morocco teaching English as a Peace Corps volunteer. She studied MA in a two-month intensive program and was appointed to teach English in a small rural town in Morocco, where her medium of communication was mainly MA. When this study began the subject had not used MA for about four years.

The data in this study consist of twelve narratives in MA collected over a four-week period during daily casual conversations. The conversation sessions usually lasted between 45 minutes and one hour. The subject appeared to be relaxed and the tape recorder did not seem to bother her at all. The data were transcribed immediately after each session, and notes concerning the context (setting, participants, subject's attitude, some of her actions and gestures) were also made.

The choice of narrative discourse as our focus is justified by the following considerations. A narrative, which is a way of reporting past events and experiences, is an easily recognizable discourse unit which is definable formally (i.e., it has a specific structure) and interactionally (in that it cannot be interrupted) (Linde 1979). ${ }^{2}$ It is also a fairly common discourse genre; in any speech community people tell stories and report events constantly. Furthermore, for the purpose of the present study, narrative discourse is particularly appropriate for investigating how the subject compensates for her linguistic deficiencies since the burden of communication is put almost entirely on her (cf. non-interruptability of narratives).

\footnotetext{
${ }^{2}$ It has been suggested that the interruptability of the discourse unit is a special case of turn taking as discussed in Sacks, Schegloff, and Jefferson (1974) (Linde 1979:340).
} 


\section{TYPOLOGY OF COMMUNICATIVE STRATEGIES}

In this paper I take CS to mean an alternative device used by the subject to fill in gaps in her "knowledge" of the target language. Tarone (1977, 1980) states that language learners' use of these strategies is motivated by the desire to convey a meaning. I would further suggest that the use of strategies is also motivated by discourse requirements. It will be shown later, for instance, that the subject's innovative use of pronouns served to keep the reference to the participants in the narratives straight. Thus, although this discussion relies on Tarone's work, some strategies different from those mentioned by Tarone are hypothesized since my focus is on spontaneous narrative discourse. It might well be the case that different strategies are employed in different discourse genres.

The CSs which will be discussed are the following: circumlocutions, lexical borrowing, elicitation of vocabulary, use of formulaic expressions, and innovation in morphosyntax. This list of strategies is by no means exhaustive, but the strategies identified seem to be the most frequent in the data under study and, I believe, relevant in that their interaction with narrative discourse features sheds light on the way they are used.

\section{Circumlocutions}

Circumlocutions are a strategy employed by the subject to describe the characteristics of an object or an action instead of using the appropriate TL structure (Tarone 1977:198), e.g.:

(1) S: waḥed ražel li kaydir... kayșawb Imakla

a man who does makes food
meaning "the cook"

The following clues were used to identify instances of circumlocutions:

a. The subject's admission that she didn't know the exact structure in the target language:

(2) S: waḥed ražel li kaydir... kayṣawb lmakla. mane'raf̌s a man who does makes food. I don't know

kifaš ngul ism dyal xedma.
how to say name of job.

b. The linguistic structure of the utterance sometimes indicated that the subject was going to use the appropriate TL form but since this form was unavailable to her, she resorted to circumlocution: 

(3) S: Mandy kanmši fi... fi... well qrib qrib hdaya Mandy goes in in near near near me ḥdaya. near me.

The intended meaning is "Mandy walked by my side." The word ženbi, "side," which would fit after $f i$ (i.e., fi-ženbi, lit. "in my side"), was unavailable to the subject. After some hesitation, the subject used circumlocution.

c. Sometimes the subject first used a native language form and then circumlocution in the $\mathrm{TL}$ to express the same meaning:

(4) S: xas te... xas te... pretend xas tkun bhal xas

You must you must pretend you must be as if you must

tdir mika makatšufhumš.

do as if you don't see them.

\section{Lexical borrowing}

This strategy consists of the subject's using native language terms as another way of compensating for her linguistic deficiencies. This strategy is referred to extensively in the literature (Kellerman 1977; Tarone 1980; Færch and Kasper 1983). My use of the term borrowing is closest to Corder's (forthcoming). The fact that the interviewer knew English seemed to encourage the subject to resort to this strategy quite often: ${ }^{3}$

(5) S: walakin hiya u ana... screamed. but she and I screamed

\section{Elicitation of vocabulary}

The subject asked for the correct TL form, which was not available to her. This was done in two ways:

a. The subject used a full interrogative sentence to ask for assistance:

(6) S: asmitu bird?

What's the name for "bird"?

\footnotetext{
${ }^{3}$ Sometimes the borrowed item is a phrase. This is due, in certain cases at least, to properties of the TL and how the borrowed item will fit in TL structures. For example, the subject once used the phrase kicked him in an MA sentence. The vocabulary item that was unavailable to her was kick. But if she had used only kick and not him in the TL structure she would have been compelled to use the MA object clitic $u$ on this verb. The result would be something like $k i k u$, which would be an unrecognizable form.
} 
b. The subject used a question intonation on the native language word:

(7) S: kain bezaf talž 'la fug lard u šariyat šariyat There is a lot of snow on top of the ground and [approximation] roads? roads?

I: šawari‘ roads

S: wa - wa'ra difficult

\section{Expanded use of formulaic expressions}

Formulaic expressions are fixed structures with a syntactically restricted and situationally determined use (Fillmore 1976:292). They are "felt and handled as a unit" (Jespersen 1924). The subject's strategy consists of expanding the use of these expressions to syntactic and semantic contexts in which they never occur in native speech. For instance, the expression makain muškil, which is equivalent to the English "It doesn't matter," "That's OK," or "No problem," may be used only in exchanges like the following:

(8) A: smeḥ liya nsit ma žebtš lektab dyalek. Sorry I forgot to bring your book.

B: makain muškil.

That's OK.

The subject used the same formula to express the fact that she escaped without harm from an incident where she was attacked by dogs. The use of that formula in this context is clearly deviant from a TL perspective:

(9) S: makain muškil walakin xeft.

No problem but I was frightened.

The expansion of use of formulaic expressions sometimes violated syntactic restrictions in the TL. The expression meskina! "poor girl!" which serves to express pity and compassion, cannot take a modifier. Yet, the subject violated this syntactic restriction by using the modifier bezaf, "very." This is clearly not a case of language transfer, as this restriction is also true for the equivalent English expression.

(10) S: meskina! bezaf meskina!

Poor girl! *Very poor girl! 
My guess is that the subject wanted to express the intensity of her feelings of compassion towards the person referred to here. A native speaker of MA would probably say something like the following:

(11) bqat fiya bezaf.

I really felt sorry for her.

In a sense, then, the expression meskina plus the modifier bezaf in the subject's interlanguage is a simpler way of conveying the same message since it reduces the amount of verbal activity on the part of the subject, although the result is syntactically deviant.

\section{Morphosyntactic innovation}

In MA, a Pronoun Drop rule deletes the (free morpheme) subject pronoun, and reference to the subject is achieved by verb inflections, e.g.:

(12) mš-at went-she "she went"

The pronoun subject is used only in cases of emphasis or contrast, e.g.:

(13) ana dxalt u hiya xeržat. 1 entered and she went-out-she.

The subject in this study had difficulties employing the correct verb inflections and thus compensated for this deficiency by using the pronoun subject. Example:

$\begin{array}{lllll}\text { S: meli huwa šaf haduk mšaw huwa nuḍ } \\ \text { when he saw those went away he } & \text { got up } \\ \text { baš } & \text { yḍrub telefon. } & & \\ \text { to } & \text { make a telephone call. }\end{array}$

However, sometimes the subject applied the Pronoun Drop rule, even though the verb inflections were incorrect. It will be shown later that the application of this strategy is related to whether or not the participant in a narrative is in focus.

\section{THE USE OF CSS IN THE NARRATIVES}

The subject's innovative use of the Pronoun Drop in MA is different from the other strategies in that it concerns syntactic relations rather than the lexicon and thus calls for separate treatment. It will be dealt with below, 
under A Morphosyntactic Innovation. In the subsection The Relationship Between the CSs and Discourse Structure, I will try to show that the other CSs are not used randomly in the subject's narratives, but on the contrary, that the choice of a particular strategy is determined by the part of the narrative under consideration. First, however, it is necessary to examine the subject's narrative discourse structure.

\section{The subject's narrative discourse structure}

I mentioned earlier that a narrative is a way of reporting past events and experiences. However, as has been noted in studies on narrative discourse (Labov and Waletzky 1967; Labov 1972; Grimes 1975; Linde, forthcoming), speakers do not simply "report the state of the world" (Grimes 1975), but add other information (feelings, evaluations, etc.). Thus in addition to the reported events themselves, narratives comprise other elements. Labov, in his analysis of narratives by black speakers of English (1972), states that "a fully formed narrative may show the following: (1) Abstract, (2) Orientation, (3) Complicating action, (4) Evaluation, (5) Result or resolution, (6) Coda." In his study of the Philippine narrative, Longacre (1968, cited in Linde 1974) discovered similar structural properties of narrative in many Philippine languages (although the terminology he uses is different from Labov's-see Linde 1974:36).

Although our main concern here is the subject's narrative discourse, a word on MA narrative discourse is in order. To the best of my knowledge, there exist no studies of MA narrative discourse. Therefore, I examined five narratives by native speakers of MA in order to develop an idea of the structure of Moroccan narrative. The five narratives exhibit, in general, structural elements similar to those mentioned in Labov (see Appendix). However, a word of caution is necessary: Given the extremely small amount of data considered, it is unreasonable to claim that MA narratives are similar in structure to the narratives examined by Labov. In particular, I should mention that the five narratives came from educated MA speakers who studied in French-system schools and who were very fluent in English. It would not be surprising if older, largely uneducated MA speakers reported past events and experiences quite differently.

The subject's twelve narratives also exhibit similar structures to those mentioned in Labov, although the structural elements may not all be present in any one narrative. In order to facilitate the discussion, I will use 
some of the terminology in Labov (1972). In general, the subject's narratives include, then, the following elements: abstract, orientation, episodic component, evaluation, and coda.

The abstract sums up the point of the narrative, e.g.:

$$
\begin{array}{lllll}
\mathrm{S}: & \text { kan 'andi kan 'andi ksida. had si } \\
\ldots & \text { I had I had an accident. This is } \\
\text { 'laš } & \text { 'andi hadi (points to a little scar on her face). } \\
\text { why I have this. }
\end{array}
$$

This abstract states two things: first the fact that the subject had had an accident and then the result of this event on her present state (a scar). ${ }^{4}$

The orientation is the part of the narrative in which the narrator provides information about the time and place of the events of the narrative and identifies the participants to be involved in those events (see examples (20) to (25), below).

The episodic component is operationally defined here as the utterances that report the events of the narrative (i.e., that tell what happened; see example (18), below).

The evaluation is a narrative component which serves to convey the point of the story. Labov (1972), Linde (forthcoming), and Polanyi (1979) have shown that the narrator has the obligation of showing why the story is worth telling-what makes it reportable. A narrative which lacks evaluation would seem odd. (See examples (28) to (31), below.)

The function of the coda is simply to signal that the narrative is finished. The subject used codas to operate a temporal or spatial shift, e.g.:

(16) S: walakin heta daba malqawhumš. but up to now they haven't found them.

This sentence removes both the narrator and listener from the time of the narrative events to the present (cf. Linde 1979).

\footnotetext{
${ }^{4}$ It seems that one of the main functions of the abstract is to allow the subject some time to recall the events before starting the narrative proper. Typically, the narratives which do not have an abstract begin in the following manner:

(interviewer's request)

S: waxa, waxa... [+ silence $]$

OK OK

The word waxa implies that the subject is willing to fulfill the request and the silence that follows will thus not be annoying for the interviewer, but simply suggests that the subject is in the process of recalling the events and possibly thinking of the best way to encode them. This kind of beginning is mutually exclusive with the abstract, thus suggesting that they both have the same function (i.e., to gain some time).
} 
(17) S: șafi. mšina fhalna.

That's it. We went away.

This sentence suggests the end of the narrative by removing the participants from the place where the events of the narrative occurred.

I should mention, however, that in the data under study, these elements do not have the same importance. In particular, the abstract and the coda may not appear in the narrative. Thus, it seems that the subject's narrative has a minimal structure consisting of the orientation, the episodic component, and the evaluation. In fact, all the twelve narratives, except one (see example (26)), comprise an orientation, an episodic component, and evaluations. Three narratives start with abstracts and two end with codas.

\section{The relationship between the CSs and discourse structure}

The point that will be made in this discussion is that the structural element considered (orientation, episodic component, or evaluation) determines to a large extent the strategy used.

Table 1 sums up the data to be discussed below: The 45 instances of strategies identified in the narratives are cross-classified (1) by their type (circumlocution, vocabulary elicitation, etc.) and (2) by the narrative component in which they occur.

Table I

Percentage of communicative strategies in major narrative components

\begin{tabular}{|c|c|c|c|c|}
\hline \multirow[b]{2}{*}{$\begin{array}{l}\text { Narrative } \\
\text { component }\end{array}$} & \multicolumn{4}{|c|}{ Communicative strategies } \\
\hline & Circumlocutions & $\begin{array}{c}\text { Lexical } \\
\text { borrowing }\end{array}$ & $\begin{array}{c}\text { Elicitation } \\
\text { of vocabulary }\end{array}$ & Formulas \\
\hline Orientation & $39(7)^{*}$ & $33(6)$ & $28(5)$ & 0 \\
\hline Episodic component & $18(2)$ & $73(8)$ & $9(1)$ & 0 \\
\hline Evaluation & $25(4)$ & $6(1)$ & $6(1)$ & $63(10)$ \\
\hline
\end{tabular}

* Raw frequencies appear in parentheses.

Orientation vs. episodic component: differential application of CS. As shown in Table 1, circumlocutions, lexical borrowing, and elicitation of vocabulary occur with relatively equal frequency in the orientation (i.e., there does not seem to be a constraint on the choice of one or the other). This contrasts with what happens in the episodic component, where lexical 
borrowing is the main CS employed. ${ }^{5}$ We should notice, however, that what is unexpected here is not so much the fact that the choice of CS is not constrained in the orientation, but rather that lexical borrowing is the main strategy employed by the subject in the episodic component. In other words, the latter case is the marked one. How, then, can we account for this phenomenon?

I think that in the episodic component, the part of the narrative in which the events are recounted, the choice of CS is constrained by the urgency to convey meaning to the listener. The narrator is in the process of relating the events to an intrigued listener and her attention is focused on telling what happened rather than on the code. The use of circumlocutions and especially elicitations of vocabulary would delay the transmission of messages to the listener. The narration of the events, which is indeed the main purpose of the narrative, would be overshadowed by metalinguistic discussion of the TL (i.e., vocabulary elicitation). Thus, by avoiding circumlocutions and elicitations of vocabulary, the subject made her narration more effective. Let's consider the following example:

(18) S: huwa sma' ši wah- huwa sma' (knocks on the table to imitate he heard somebod-he heard

footsteps) urah urah u meli dur baš yšuf ašnu

hadši ašnu lte-happened. what was happening wahed ražel this was what - happened. What was happening a man darbu. waxa huwa theh $\mathrm{m}$... 'la (points to the ground) $\mathrm{u}$ hit him. OK he fell $m$ on and ražel laxur kicked him. the other man kicked him.

In this example, four vocabulary items were not available to the subject: footsteps, happen, ground, and kick. In none of these instances did the subject interrupt the narrative to elicit these items, as she often did in the orientation by asking a question such as "Whats the word for ...?" or "Can I say...?" Instead, she used gestures (pointing to the ground), acting

\footnotetext{
${ }^{5}$ The subject also used gestures in the episodic component, as shown in example (18). Unfortunately, this strategy is not considered in this study because it is impossible to note down all gestures. I think any systematic study of gestures should be carried out with appropriate equipment (videotape).
} 
(knocking on a table), and straightforward borrowing from her native language (happen, kick).

It seems, then, that once the narrator is launched into reporting the events (the episodic component) to the intrigued listener, it would be less effective for her to interrupt the narrative at this point in order to elicit vocabulary items or even delay the flow of messages by using circumlocutions. Instead, she resorts to lexical borrowing to compensate for her linguistic deficiencies.

In the orientation section, on the other hand, no such pressure (i.e., the urgency to convey information rapidly) is put on the narrator. The narrator is more preoccupied with giving sufficient information about the time, the place, and the participants that will be involved in the events to be reported. In one instance, the subject explicitly stated her preoccupation that the listener grasp what she wanted to say:

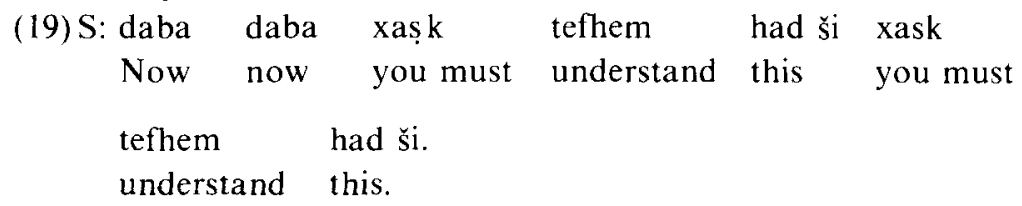

The information in the orientation is essential in order for the listener to understand what follows. The listener may in fact build up a certain number of expectations about possible outcomes on the basis of that information alone. To make sure that the listener did not miss such information, the subject tried circumlocutions, asked for help in encoding meaning, or even resorted to a nother code (in this case, English) with which the listener was familiar. Below are instances of CSs taken from orientation sections:

Circumlocutions

Identification of participants:

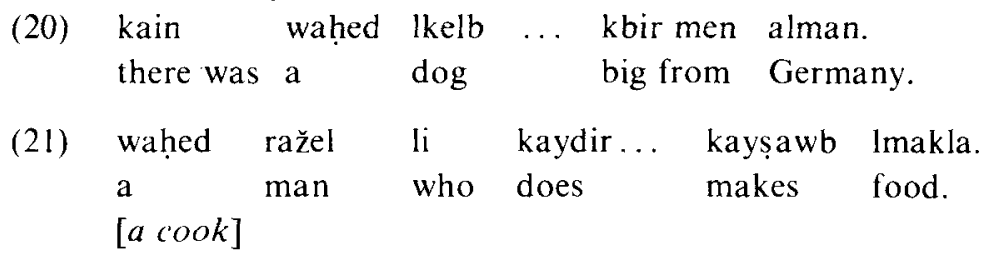

Lexical borrowing

Specification of place:

$\begin{array}{lllll}\text { (22) xasu } & \text { ybda } & \text { f- } & \text { wahed lotel popule. } \\ \text { he must } & \text { start } & \text { in } & \text { a } & \text { popular hotel. }\end{array}$ 
Identification of participant:

(23) huwa huwa kaykun m‘a ši- m'a teda- tedabib students he he was with some- with [approximation] students.

Elicitation of vocabulary

Specification of place:

$\begin{array}{lllll}\text { kain } & \text { bezaf leklab } & \text { qedam } & \text { babi } \\ \text { there were } & \text { a lot of } & \text { dogs } & \text { in front of } & \text { my door }\end{array}$

fi žran ašnu neighborhood?

in [approx.] what is neighborhood?

25) kain bezaf telž 'la fuq larḍ u

there was a lot of snow on the ground and

šaryat šaryat roads?

[approx.] roads?

It seems, however, that the amount of information provided in the orientation section (and, consequently, the frequency of the subject's use of CSs) depends on the occurrence of narrative in the conversation and its relation to the general topic of the conversation (speech event). If the narrative occurs "naturally" in the middle of a conversation, the orientation may be reduced, or even nonexistent, depending on the extent to which the previous part of the conversation was related to the point of the narrative. In one of the conversation sessions, the subject and I were talking about a recent fire that destroyed a clothes store. In the middle of the conversation I asked her to tell me exactly what had happened:

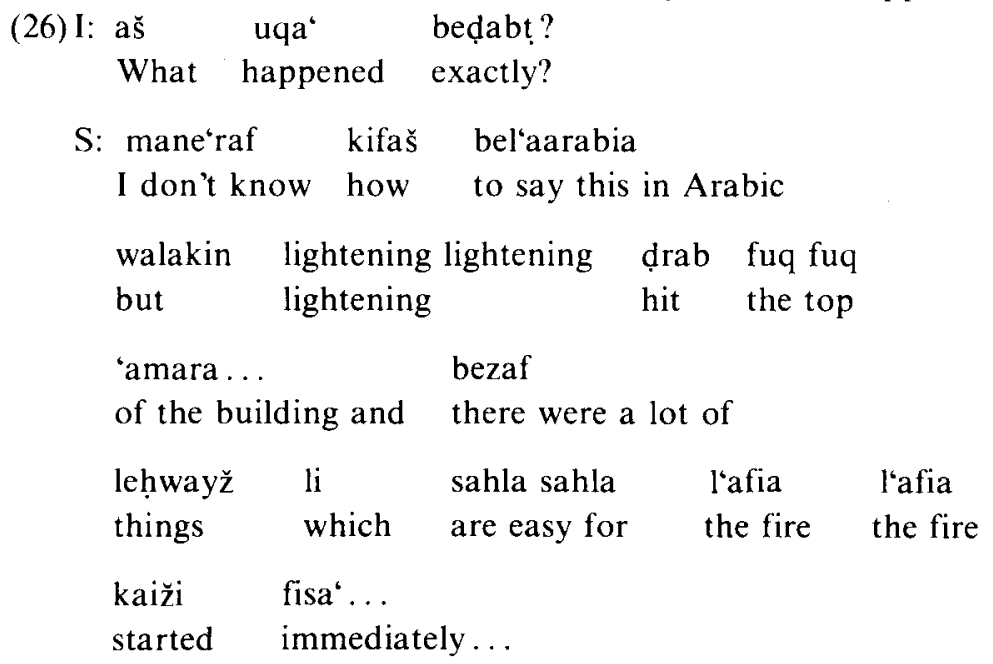


At the beginning of this narrative, the subject started relating the events immediately with no orientation since in the previous part of the conversation, information concerning the time and place of the events had been discussed.

Another factor that may determine the content of the orientation is whether or not the narrator and the listener share experiences. In this case, the subject and the interviewer did share some experiences. It would be redundant for the narrator (the subject) to elaborate, for example, on the identification of participants or places that she knew the interviewer to be familiar with. The subject had to use her own judgment about what information was to be explicitly stated and what information was to be assumed known to the hearer. This was not an easy task for her; whenever in doubt she would check. In the following example the subject identified a participant by using her name and then went on to make sure that no further specification was needed:

(27) S: ... mšit flbus li gatlik lrbaț u
I went on the bus I told you to Rabat and
kain $\mathrm{m}$ - $\quad$ kain m'aya Mandy. [identification]
there is - there is with me Mandy.
'rafti $\quad$ Mandy? [checking]
you know Mandy?

Evaluation: heavy reliance on formulaic expressions. I mentioned earlier that the evaluation is an essential component of a narrative. The nonnative subject as well as the Moroccan native speakers (NSs) constantly provided evaluations by explicitly stating why they told the story or expressing their attitudes towards the participants and events in the narratives. Linde (forthcoming) states about the function of evaluation: "There are at least two such functions which we can distinguish. One is to establish reportability, and the other is to establish reference to values and norms about the way things should be."

These two functions are illustrated in the following examples:

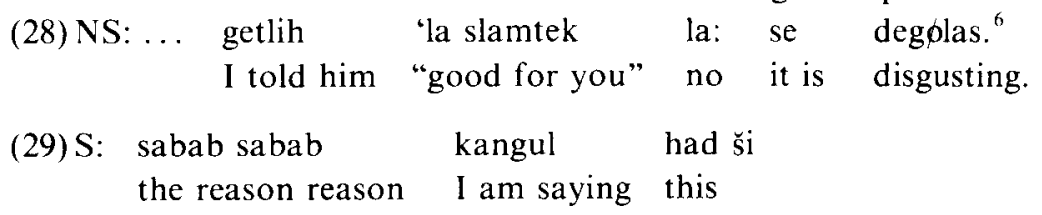

\footnotetext{
"It is interesting to note that the MA speaker sometimes gave evaluations in French, particularly by using routine expressions (e.g., C'est degueulasse).
} 


$\begin{array}{ll}\begin{array}{l}\text { 'laḥaqaš } \\ \text { is because }\end{array} \text { Mandy kan-kant m'ana u } \\ \text { (laughter) } & \text { xaift! } \\ & \text { was frightened! }\end{array}$

The native speaker mentioned previously that he had advised one of his friends to move from a dangerous neighborhood in New York, but that his advice had not been taken. In the narrative he told me how his friend was attacked in that neighborhood. In the evaluation, the narrator expressed his attitude towards the incident ("it is disgusting") and also expressed the belief that it was partly his friend's fault, since he refused to move from that neighborhood. The subject, on the other hand, established the reportability of her story in an explicit way ("The reason I am saying this ... ") after she told how she and her friend, who lived in the city and thus was not used to dealing with stray dogs, were attacked by dogs in a rural Moroccan town.

We will now consider the subject's use of formulaic expressions to fulfill this important narrative requirement (i.e., to give evaluation). In the first few narratives the subject used mainly formulaic expressions to provide evaluation, even though her use was deviant from TL norms (cf. violations of restrictions on formulaic expressions under Expanded Use of Formulaic Expressions above). Expressions like makain muškil, "No problem," meskina! "Poor girl!" ma'liš, "It doesn't matter," are structurally simple but quite efficient in expressing the subject's attitude when interpreted in the context in which they occur. The fact that all these kinds of expressions occur in the evaluation section (see Table 1) should not be surprising given the nature of such expressions. In fact, they do not have a strong referential function but rather an emotive one, which makes them appropriate for expressing attitudes (i.e., giving evaluations).

The above discussion tends to illustrate the primacy of discourse constraints: Rather than violating the requirement that every narrative must have an evaluation component, the subject resorted to formulaic expressions even at the cost of violating the restrictions on their use (cf. Expanded Use of Formulaic Expressions above).

We should mention, however, that towards the end of the study the subject was able to provide more elaborate evaluations instead of using mainly formulaic expressions as evaluations. This, I believe, is partly due to re-exposure to the TL. The following evaluations are taken from two versions of the same narrative. The first version was obtained at the beginning of the study (Time 1), the second version, four weeks later (Time 
2) when another Moroccan speaker asked the subject to tell him the same story.

Time I

(30) $\mathrm{S}:$

$\begin{array}{lll}\text { makain muškil } & \text { walakin } & \text { xeft } \\ \text { No problem } & \text { but } & \text { I was frightened. }\end{array}$

Time 2

(31) $\mathrm{S}:$

\begin{tabular}{|c|c|c|c|}
\hline $\begin{array}{l}\text { xeft } \\
\text { was frighten }\end{array}$ & hed $\begin{array}{ll}\text { bezaf } & \text { 'al } \\
\text { a lot } & \text { be }\end{array}$ & $\begin{array}{l}\text { aḥaqaš } \\
\text { cause }\end{array}$ & $\begin{array}{l}\text { kan 'andi } \\
\text { I had }\end{array}$ \\
\hline $\begin{array}{l}\text { težriba bezaf } \\
\text { many experiences }\end{array}$ & $\begin{array}{l}\text { m'ahum } \\
\text { with them [dogs }\end{array}$ & $\begin{array}{l}\text { u } \\
\text { and }\end{array}$ & \\
\hline xeft. & maši & leklab & hna \\
\hline I was frightened. & It's not & dogs & \\
\hline
\end{tabular}

In (30) the subject used the formula makain muškil, "No problem," albeit inappropriately, to express the effect on her of the experience of being attacked by dogs; she had no major problem dealing with the situation but she was frightened. The evaluation in (31) is more elaborate. The subject not only expressed her reaction to the situation ("I was frightened") as she did in (30), but she went on to explain the reason for such a reaction ("because I had many experiences with them") and even provided a comparison ("It's not like dogs here in the U.S."). Notice that the elaboration in (3I) results in more complex sentence structures: use of subordination and comparatives.

\footnotetext{
${ }^{7}$ As Labov (1972) has shown, the syntax of the evaluation is more complex than that of the episodic component (or the "narrative clauses" in Labov's terminology). Compare the evaluations in (31) to the utterances taken from episodic components:

Labov's data

(1972:360)

This boy punched me

NS of MA

and I punched him

and the teacher came in

and stopped the fight

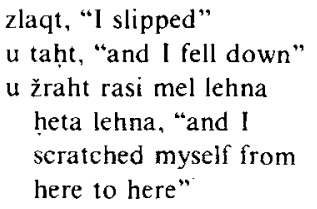




\section{A morphosyntactic innovation: the pronoun drop rule and reference to participants}

One of the important tasks of the narrator is to keep the reference to the participants straight. It is essential that the listener understand who is doing what to whom. In MA, the morphological markings on the verb may include reference to both the subject and the object, e.g.:

(32) darb-at-u

hit-she-him

"she hit him"

A free morpheme subject pronoun is used only exceptionally to indicate contrast, for instance:

(33) hiya darbatu

she hit-she-him

"she (not someone else) hit him"

The subject had enormous difficulties in using the correct inflections on the verb, which interfered with the proper reference to the participants in the story. I will show here how the subject compensated for this deficiency by using the pronouns in a creative and principled way. The following "rules" seem to be at play:

1. If the participant is in focus, as is the case in stories with one character, the first reference to the participant may be achieved through the use of a pronoun, but in subsequent clauses the pronoun is dropped, even though the inflections on the verbs are incorrect. Example (incorrect inflections are indicated by inc.):

S: huwa
He
kmu
smoke-h
(inc.)
_
bisiklet dyali
mšiw 'la ražliha
sa niya
na ši haža
lklab

$\begin{array}{llll}\text { mša } & \text { n'es. meli } & \text { dir } & \text { had ši } \\ \text { went } & \text { to sleep. When } & \text { did-he this } \\ & \text { (inc.) } & & \text { (inc.) }\end{array}$

\footnotetext{
Subject

rkabt lbisiklet dyali

u hiya mšiw la ražliha

hdaya

mšiw bšwiya

u sma'na ši haža

sma'na lklab
}

"I got on my bicycle"

"and she went on foot

beside me"

"we went slowly"

"and we heard something"

"we heard dogs" 
$\begin{array}{llll}\text { rasu } & \text { garo } & \text { taht } & \text { la fuq lefraš. } \\ \text { his head } & \text { the cigarette fell on top of the bed. }\end{array}$

In this case the listener does not have any problems tracing the referent since only one participant is in focus and thus ambiguity is not possible.

2. When more than one character is involved, the subject pronoun is not dropped (even though, sometimes, the inflections are correct and would be sufficient to keep the references straight). Example (her friend was attacked by two men in the street):

(35) S: huwa gles gles tema šwiya u meli huwa He sat sat there a while and when he

s̆af haduk mšaw huwa nuḍ bas̆

saw those went away he got up to

yḍrub telefon.

make a telephone call.

Sometimes the subject attempted to use inflections only, but being uncertain about the correct inflection, she would give up:

(36) S: mšit m'aya mšat? [S gives up and

went-I with me... went-she?

(inc.)

uses a full NP]: Mandy mšat m'aya.

Mandy went-she with me.

3. When the subject overtly used the pronoun she did not worry about the inflections on the verb. However, when she applied the Pronoun Drop rule, she attempted self-corrections. Examples:

(37) S: hiya žrit she ran-I (inc.)

$$
\begin{array}{clll}
\text { S: qbel ma } & \text { xeržu } & \ldots & \text { xrežna } \\
\text { before } & \text { went-out-they } & \ldots & \text { went-out-we } \\
& \text { (inc.) } & &
\end{array}
$$

In example (37), the correct verb form is zrat ("ran-she"), but the subject did not bother to correct the inflection because the pronoun was used, thus ambiguity of reference was avoided. In the second example, where the pronoun was not used, she attempted self-correction (the intended meaning is "we went out"). Indeed, ambiguity would have resulted if she hadn't.

Table 2 shows the pattern underlying the subject's use of the Pronoun Drop rule. This analysis indicates how the subject compensated for a 
Table 2

The pattern of the subject's use of the pronoun drop rule

\begin{tabular}{ccc}
\hline \hline Participant in focus & Pronoun present & Self-correction \\
\hline- & + & - \\
+ & - & - \\
- & - & + \\
\hline
\end{tabular}

linguistic deficiency (i.e., verb inflections) through innovations in the morphosyntax of the TL. It also shows the importance of discourse considerations in identifying the underlying pattern of the use of the pronoun subject. In traditional error analysis, the use of the pronoun in this case would simply be considered as a nonsystematic error (sometimes the rule is applied correctly and sometimes it is not); the analysis of the subject's discourse, however, sheds more light on this phenomenon and tends to indicate a systematic pattern of pronoun use governed by discourse features.

\section{CONCLUSION}

\section{Summary}

The above analysis suggests the following conclusions:

1. In spite of her evident linguistic deficiencies, the subject managed to communicate effectively by using various CSs to compensate for these deficiencies and fulfill a number of essential narrative discourse requirements.

2. Discourse considerations provide a better understanding of the application of CSs. Thus, instead of simply saying that the subject used certain strategies, we were able to provide a deeper insight into the application of these strategies within a specific discourse genre. In fact, it was revealed that the application of CSs was constrained by narrative discourse features.

\section{Limitations and suggestions for further research}

First, the data in this study are quite limited. We have dealt with only one subject and one discourse genre (narratives). However, the results of this study suggest a few conclusions that should be tested further with more 
subjects and different types of discourse. In particular, it would be interesting to see if second language learners use CSs differently for different discourse genres. There is evidence, for instance, that the subject in the present study used CSs differently depending on the discourse genre. We have discussed earlier (see A Morphosyntactic Innovation, above) how the subject compensated for her deficient use of verb inflections by using free morpheme pronouns in order to keep reference to participants straight in the narratives. In procedural discourse, on the other hand, she did not resort to such a strategy. This can be explained by the fact that in procedural discourse the focus is on processes rather than on the agents (i.e., the doers of the action). Example (the subject was asked to explain how to make couscous, a popular dish in Morocco):

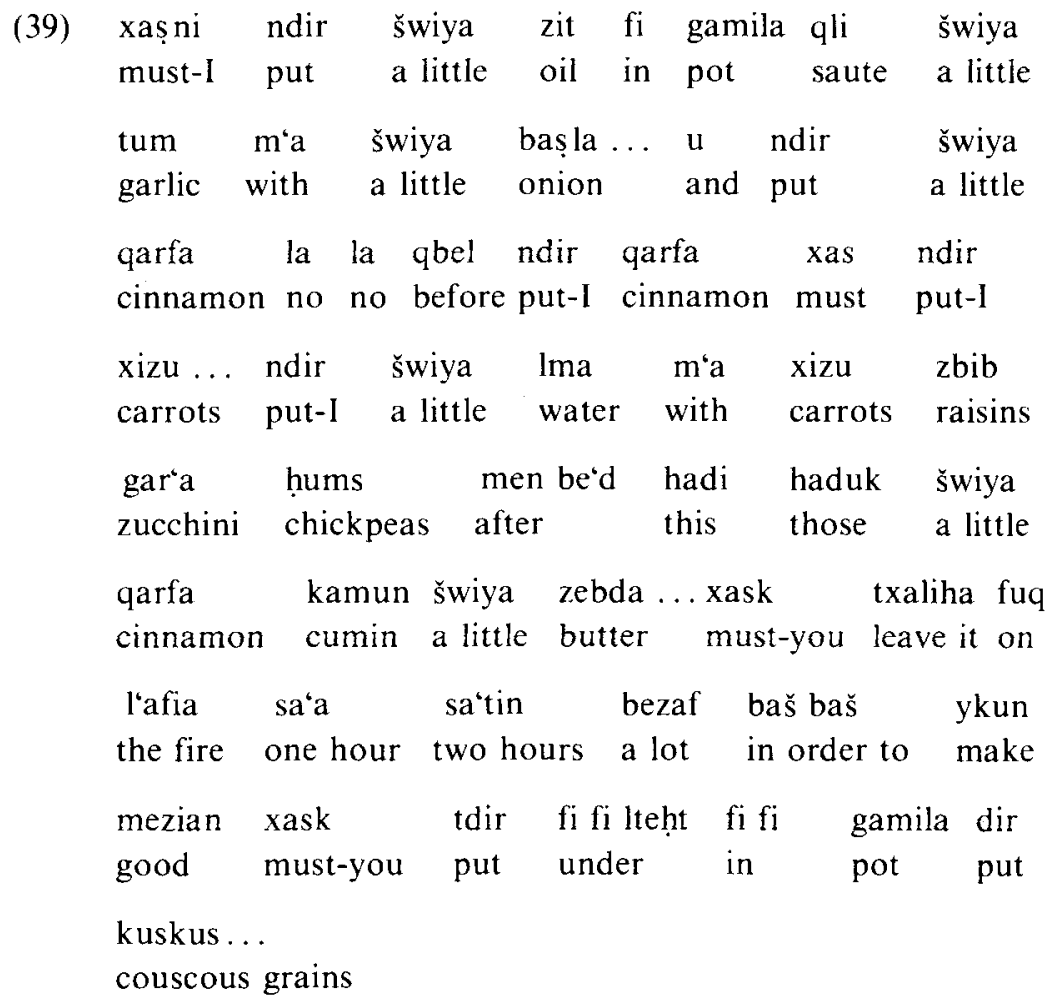

In this example of procedural discourse the subject never used the free morpheme pronoun subject. Instead, she used first person inflections (e.g., xașni, "must-I," ndir, "put-I"), second person inflections (xask, "mustyou," tdir, "put-you") or simply the base of the verb (qli, "saute," xas, "must," dir, "put"). In contrast to narratives, where the specification of the 
participant is crucial (the listener must know who is doing what to whom), in procedural discourse, specification of the agent or doer is not as important.

\section{REFERENCES}

Corder, S.P. 1983. Strategies of communication. In Strategies in Interlanguage Communication, eds. C. Færch and G. Kasper. London: Longman.

Corder, S.P. Forthcoming. A role for the mother tongue. In Language Transfer in Language Learning, eds. S. Gass and L. Selinker. Rowley, Mass.: Newbury House.

Færch, C., and G. Kasper, eds. 1983. Strategies in Interlanguage Communication. London: Longman.

Fillmore, L.W. 1976. The Second Time Around: Cognitive and Social Strategies in Second Language Acquisition. Ph.D. dissertation, Stanford University.

Galvan, J., and R.N. Campbell. 1979. An examination of the communication strategies of two children in the Culver City Spanish immersion program. In The Acquisition and Use of Spanish and English as First and Second Languages, ed. R.W. Andersen. Washington, D.C.: TESOL.

Grimes, J.E. 1975. The Thread of Discourse. The Hague: Mouton.

Jespersen, O. 1965. The Philosophy of Grammar. New York: W.W. Norton. (Originally published in 1924 by Allen and Unwin.)

Kellerman, E. 1977. Towards a characterization of the strategy of transfer in second language acquisition. ISB 2:58-146.

Labov, W. 1972. The transformation of experience in narrative syntax. In Language in the Inner City. Philadelphia: University of Pennsylvania Press.

Labov. W.. and J. Waletzky. 1967. Narrative analysis. In Essars on the Verbal and Visual Arts, ed. J. Helm. Seattle: University of Washington Press.

Linde, C. 1974. The Linguistic Encoding of Spatial Information. Ph.D. dissertation, Columbia University.

l.inde, C. 1979. Focus of attention and the choice of pronouns in discourse. In Syntax and Semantics: Discourse and Syntax, ed. T. Givón. Vol. 12. New York: Academic Press.

Linde. C. Forthcoming. The organization of discourse. In The English Language: English in Its Social and Historical Context, eds. T. Shopen, A. Zwicky, and P. Griffin. Boston: Winthrop.

Longacre, R. 1968. Discourse, Paragraph and Sentence Structure in Selected Philippine Languages. Final Report \#0-8-062838-0391. Washington, D.C.: Office of Education, U.S. Department of Health, Education and Welfare.

Polanyi, L. 1979. So what's the point? Semiotica 25:207-241.

Sacks, H., E. Schegloff, and G. Jefferson. 1974. A simplest systematics for the organization of turn-taking for conversation. Language 50,4.

Selinker. L. 1972. Interlanguage. IRAL 10:209-231.

Tarone. E. 1977. Conscious communication strategies in interlanguage: a progress report. In On TESOL 77: Teaching and Learning English as a Second Language, eds. H.D. Brown, C. Yorio, and R. Crymes. Washington, D.C.: TESOL.

Tarone, E. 1979. Some Thoughts on the Notion of "Communicative Strategies." Paper presented at First TESOL Summer Institute, UCLA.

Tarone, E. 1980. Communication strategies, foreigner talk, and repair in interlanguage. Language Learning 20:417-431.

Varadi, T. 1973. Strategies of Target Language Communication. Paper presented at the VI Conference of the Romanian-English Linguistics Project in Timisoarn. 


\section{APPENDIX}

\section{Examples of Narratives from the Data*}

\section{A NARRATIVE BY A NATIVE SPEAKER OF MA:}

wahed l'iraqi hadak (taboo word). huwa sakn fwahed lkartie An Iraqi guy was mugged. He lived in a very bad

mqawed u kangulih awedi rah maxasekš tebqa temma. thawel neighborhood and I always tell him you shouldn't stay there. Move

lkampus ula thawel lši kartie axur. wahed nhar gadi huwa u to the campus or move to a nother neighborhood. One day he was walking

saḥebtu. šeduh ža waḥed xayna hat lih lmus 'la "engu (laughs).

with his girlfriend. They caught him a guy came and put a knife on his dawlih hadak meskin qawduha 'lih dawlih lportf $\phi y$ neck. They took - that poor guy they abused him they took his wallet

kulu ... fhemtini... dawlih lportf $\phi y$ kulu ga“ I.D. dyalu binšurans you know they took "all" his wallet his I.D. with insurance

b-kulsi le papie daylu mšaw lih. darbu waḥed xayna lwažhu... with-all his papers were gone. A guy hit him in the face... darbu Ifumu. mšaw drari shabu l'iraqiyin dawh lsbitar he hit him in the mouth. His Iraqi friends took him to the hospital

flil u sda‘ (laughs). 1申 lãdemẽ tlaq lapartmã (laughs). at night a real hassle. The next day he moved out of the apartment. getlih 'la slamtek la se degфlas. I told him "good for you." No it's disgusting.

*I tried to make the translation reflect the original as much as possible without obscuring the meaning. 


\section{A NARRATIVE BY THE SUBJECT:}

Kain 'andi wahed sahebti flil u hiya sakna frbat

There was a friend with me at night and she lived in Rabat

u xasha tke - tku- tkun frbat baš tqari tqari f̌̌ami‘a.

and she had to be in Rabat in order to teach at the university.

'andha durus m'a l'ašra. waxa mšit m'ha baš tidiw hadak lkar...

She had class at ten. OK I went with her to take that bus...

walakin hiya sakna frbaṭ u ma ma kate'rafš muškil dyal leklab (laughs).

but she lives in Rabat and doesn't know 'the problem of dogs'.

mšit m'aha walakin... rkebt bisiklet dyali u hiya mšiw 'la fražliha I went with her but I got on my bicycle and she went on foot

ḥdaya ḥdaya waxa mšiw bšwiya mšina bšwiya (laughs) bšwiya u sme‘ near me OK we went slowly we went slowly slowly and hear

sme'na ši haža 'rafti 'raftu (laughs) sme'na leklab u ana we heard something you know we heard dogs and I

xeft bezaf 'lahaqaš kan 'andi težriba bezaf m'ahum u was frightened a lot because I had many experiences with them and

xeft. maši bhạal leklab hna flwilayat lmutahida wahe ... em

I was frightened it's not like dogs here in the U.S.-

qalebt qalebt "la ši hažrat baš luh "lihum walakin hiya ašnu? (laughs)

I looked for some stones to throw at them but she "what?"

aš gadi tdir? (laughs). bezaf klab žai lina. aš gadi ndiru?

what will she do? A lot of dogs came to us. What are we going to do?

walu xaste xaste pretend xas tkun bhal... xas tdir mika (laughs)

Nothing you must pretend you must be as if you must do as if 
xas tdir mika ma makatšufhum. katemši bhal bhal makatšufhum.

you must do as if you don't see them you go as if you don't see them.

hiya gatliya 'waxa' walakin bež - bžužna xafu...u

She told me "OK" but - both of us were frightened and

walakin klab šhal meqri bezaf $u$... u meli meli huma bhal bhal hna but dogs were very (angry?) and and when when they were like here

(points to a spot near her) 'awe-gawetna gawetna bezaf.

-we screamed screamed a lot.

I: gawetu!

You screamed!

S: gawetna bezaf walakin kain wahed game' qribna u had lwaqt

We screamed a lot but there was near us a mosque and that was the

dyal șala...u kanu qedam žame‘ bezaf šibaniyin

time of prayer and there were in front of the mosque a lot of old men

me“lum šibaniyin (laughs). u huma "awnuna "sir fhalkum!" luh

of course old men. And they helped us "go away!" They threw

hažrat. "šukran šukran šukran". safi mšina fhalna.

stones. Thanks thanks thanks. That's it we went away. 